\title{
Ethics Auditing Model for Estonian Big and Middle Size Companies
}

\author{
Merle Rihma \\ Tallinn Pedagogical College, Tallinn, Estonia
}

\begin{abstract}
The purpose of this article is to introduce ethics auditing model for Estonian big and middle size companies where the majority of ownership is held by Estonian citizens. The earlier developed ethic audit models are not suitable for Estonia, due to the limited development of business ethics in general. Firstly, the paper offers an overview of corporate social responsibility reports and auditing. Taking into account Estonian business ethics culture, cultural background and the shortcomings of social reports, the author creates a new auditing model for Estonian companies, based on stakeholders' theory. Despite the fact that only $20 \%$ of managers in Estonia are aware of ethical management tools such as ethical auditing or different social reports and standards, most of the top managers would indeed like to pay more attention towards the ethical relationships among stakeholders. It is well known, that in a long term perspective, ethics auditing can improve company's effectiveness, raise the quality of management and assure sustainability. Ethics auditing is understood as an opportunity and agreement to devise a system to inform about ethical corporate behaviour. After the upcoming actuation of the previously mentioned model, the auditing model will be examined and improved when necessary in order to guarantee its applicability per se.
\end{abstract}

Keywords: ethics auditing, trustworthiness, stakeholder theory, social audits, social reporting, sustainability

\section{Introduction}

Today's need to rebuild trust after the financial crisis and the apparent reorientation towards a sustainable economy is being translated to call for unprecedented levels of transparency. The reward of a highly ethical value system is not fame or fortune; the reward is the knowledge that you did what was right, which is far more life-enhancing than money or prominence. It is important to hold companies effectiveness and happiness together. There are needs to be more to ethics than the trust and honesty that requisite of any successful organization and the ethical strategies such as care for customers, employees and others stakeholders pay off in increased profit (Duska, 2007). Economic crisis amplifies all other crisis in the society and in human relations. Businesses which have built a bond of trust with their interest groups have a much greater chance of survival. Intuition, which is often used as an evaluating measure for the quality of the acts, may be misleading. However, objective evaluation is possible when different types of interest groups are attracted. Ethics auditing and social reports are the main tools for companies for analysing relationships between stakeholder groups and companies real activity. Transparency means that management decisions are clear, honest and open about our environmental programs and performance. Other mechanisms developed to build trust and accountability is

Merle Rihma, Vice Rector, MBA, Social Scienses Department, Tallinn Pedagogical College.

Correspondence concerning this article should be addressed to Merle Rihma, 49 Räägu, Tallinn, Estonia. E-mail: merle.rihma@eek.ee. 
different reports, performance assessment and evaluation, codes and common accepted good practices.

The aim of this article is to describe ethical auditing model for Estonian big and middle size companies where majority of ownership is held by Estonian citizens. Most of the big companies and employers in Estonia affiliates of international companies, where all strategically decisions are made in the headquarters. There are own national rules, habits and values which are common to concrete cultural society or based on companies deep cultural values.

In spite of fact that we are a Nordic country, there are some historical and cultural reasons for tendencies to act differently in comparison to Swedish or Norwegian or even Finnish people.

International trust towards Estonian companies and managers is rather poor. Companies' sustainability depends on the values, honesty, and moral of the owner or the CEO. That is the reason why it is urgent to implement regulations to improve trust with all interest groups, including investors from outside.

The implementation of the audit model can help to build trust through facilitating companies' accountability and transparency. It is important to use auditing more internal way than external way. Auditing means to help managers to make and plan right strategies and polices, not to be one passive or fictive PR element. This is evaluation of the positive and negative consequences of business activities by using criteria that consider the value to society, social performance, the environment, profitability, etc. (Büscher et al., 2005). The public decision and attitudes as well are based on the ethical choice and the grounds for observing these values are the recognition of that circumstance. Facts can never lead to direct decisions about what should be done. State of things can be described by facts but in order for the decisions about the future to be possible to make, the author needs to complement these facts with assessments. That's why all opinions and standards regarding important decisions should be made public. In spite of a rather high unemployment rate, all managers and owners think about possibilities to attract the best employees and capital on the most favourable terms. Challenges, work conditions, and microclimate are more essential for potential employees than the salary level. To get best human capital, managers have to pay attention for those aspects.

Main focus has usually been on the behaviour of managers, but less attention has been paid towards employee's attitudes and sense of responsibility. What is the role of employees in organizational surviving and how they share the responsibility for company's sustainability? There could be a lot of different codes of conducts, reports, and regulation, but if employee does not feel his/her is a part of the organization or he/she does not take part of the responsibility, the thought or the attitude towards his/her extra bonuses should not be accepted. Ethical behaviour, trustworthiness, and morality have to be internalized into every member of the organization. It could be possible in circumstances when managers and employees are real partners with mutual respect. All organizations are vulnerable to the risks of stakeholders, for example employee's misconduct or inefficiency. CEOs should promote actively environmental awareness by training and education of employees and follow efficient use of energy and materials in offices in production areas. Talking about core values of the organization in every level (employees, partners, owners etc.) helps these values and norms to become effective in everyday's life. An untrustworthy company cannot succeed in the medium- or long-term perspective. The only opportunity for success may be possible in societies where legal regulation and oversight are insufficient.

Business owners and top managers must be carefully fostered in order to create trust towards each stakeholder group and maintain a long-term license to operate. This auditing model will take into consideration of stakeholder's theory and through this one can analyse integrative roll of each stakeholder group, meaning value based on management and social responsibility. The systematic analysis helps companies 
comprehensively evaluate their own activities. Ethics auditing is more than an exercise of information gathering.

Very often organizations culture is like a nice display window-fancy and excellent-they are sponsoring culture, launching good and luxurious products, they are market leaders in ones segment, but real life inside organization is hidden and distinct from external side.

In this article, the author first gives short overview of the ethics auditing and social auditing literature, after that a background of business ethics in Estonia is given to understand better differences between old developed economy systems. Main part of this article describes auditing process and its action on the before mentioned topic.

\section{Short Overview of the Ethics Auditing Literature}

Ethics auditing is useful and objective tools for implementing good governance principles in organization. It gives trustworthiness and transparency for every stakeholder group. Auditing provides information which allows investors to evaluate the intensity of an organization's approach to social performance management, to validate the reliability of social performance information self-reported by an organization and to compare or benchmark performance between organizations. OECD (Johnston, 2004) has definite good governance as a set of eight characteristics:

- Equity and inclusiveness - to ensure that all stakeholders feel that they have a stake in the organization and do not feel excluded;

- Responsiveness — organizations, institutions and processes try to serve all stakeholders within a reasonable timeframe and within the means available to them;

- Participation—direct and indirect involvement with the organization through the ethics;

- Audit and other means open to all stakeholders;

- Consensus oriented—be prepared for, meditation between different interests in society and the community to reach a broad consensus;

- Effectiveness and efficiency—produce results that meet the needs of society at large and stakeholders in particular, while making use of the resources available and using them carefully and environmentally;

- Transparency - decisions are made and enforced in a manner that follows the organization's rules and procedures, and all relevant documents are open for inspection;

- Rule of law-good governance requires fair legal frameworks that are enforced impartially and human rights are upheld at all times;

- Accountability - is accountable to the public and to the organizational stakeholders.

Ethical auditing is strongly connected to social auditing and social reporting. For its beginning, almost 30 years ago, social auditing was mainly used by non-profit companies or social enterprises. Nowadays, different social auditing reports are widely used. Social auditing (Boyd \& Albee, 1998) is a process that enables an organization to assess and demonstrate its social, economic, and environmental benefits and limitations. It is a way of measuring the extent to which an organization lives up to the shared values and objectives. Social auditing is based on the need of organizations to create a balance in the way they plan and measure their commercial and non-commercial operations, and to prove that there is consistency between what an organization says it will do and what it actually does (Spreckley, 2008). Social auditing provides an assessment of the impact of an organization's non-financial objectives through systematically and regularly monitoring its 
performance and the views of its stakeholders. Social auditing (Centre for good governance, 2005) requires the involvement of stakeholders. This may include employees, clients, volunteers, funders, contractors, suppliers, and local residents interested in the organization. Stakeholders are defined as those persons or organizations who have an interest, or who have invested resources in the organization. The social auditing process requires an intermittent, but clear time commitment from a key person within the organization. In ethical auditing process are main roll of external independent experts. Business dictionary defines social auditing as follows: Social auditing is a process for evaluating, reporting on, and improving an organization's performance and behaviour, and for measuring its effects on society. The social audit can be used to produce a measure of the social responsibility of an organization. It takes into account any internal code of conduct as well as the views of all stakeholders and draws on best practice factors of total quality management and human resource development.

The definition for ethical auditing by a business dictionary: neutral, third-party verifiable process to understand, measure, report on, and help improve an organization's social and environmental performance. Ethics auditing is value-linked. It gives awareness of nature of the firm core values, highlights gaps between the officially stated values and those actually practised under the pressure of everyday's realities (Rosthorn, 2000). Even though the main reason for having ethical guidelines is not to provide a cookbook solution to every practice-related problem, but to aid in the decision-making process for situations that involve ethical questions. Ethics auditing topic has been discussed very thoroughly by Muel Kaptein, a professor of the University of Erasmus of Netherlands. Kaptein (1998) had defined an ethics auditing as a systematic approach which makes a description, analysis and evaluation of the relevant aspects of the ethics of an organization. An auditing process can provide information about the improvement of the organizational qualities and relationship with stakeholders. It helps to prioritize the objects and aspects to be improved. The point of the ethics auditing is found in the systematic manner in which the analysis is performed. The whole company should be monitored in all its activities and actions whilst paying particular attention to the company's stakeholders and the values that form its moral foundations (Büscher et al., 2005). At the same time, there could be concentrate for special field for example personal management or marketing activities. By performing ethical audit, the company is aware that it is an entity whose responsibilities are more than just for maximizing profit. Ethical auditing helps to capture and clarify the identity of an organization or if necessary even create new one (Büscher et al., 2005). Results of the auditing should be practical; it means that the committee should give real suggestions for improving the working environment and increasing its transparency. As Parthasarathy said (1988) former additional deputy controller and auditor general from India - there are in fact few social indicators and these have been developed by academic institutions doing research in a very narrow area and in highly artificial environmental models. It is necessary therefore that before any use is made of the so called social indicators, their relevance to the context of the programme audited has to be determined or, if it is at all possible, they should be appropriately modified. Excessive reliance on social indicators can lead to an accountant's measurement of the state of affairs rather than an intelligent auditor's evaluation.

To be ethical involves three activities: knowing the good, loving the good, and doing the good (Duska 2007). Of cause most important is basic_-knowing the good. This knowledge must be same for all members of organization. 


\section{An Overview About Estonian Companies From the Ethical Aspect}

The quality of ethical management is largely depending upon the decision-making ability of a manager and also on ethical knowledge people have. There is often an ethical conflict between earning money and doing what is good. Sustainability of society and republic depends on economic, the growth of economy. For a small country like Estonia, foreign investments play an important role in the sustainability of society. Unfortunately, trust towards Estonian economy is currently not very high. There are some researches carried out among Estonians to find out the characteristical patterns that describe attitudes towards Estonian business ethics and honesty. Survey carried out by author in 2009 among top managers and owners of Estonian middle and big size companies, gives the reason to implement more and more ethical management into Estonian society. There are around 150 middle or big size companies in Estonia owned by Estonian citizen. The study shows that only 20\% of managers are aware of ethical management tools like ethical auditing or different social reports and standards. At the same time, $75 \%$ of top managers or owners would like to pay more attention towards ethical relationships among stakeholders. 85\% of managers pay attention to their business partners' ethics. Therefore, the author can assume that in case of choosing business partner, attention is not only paid to economic aspects but also to culture, ethical decision-making, and performances. It seems to be similar in other post-Soviet countries. It is just a question of time, when there is need to follow same regulation and standards as developed countries. Year by year it is going better and better. In spring 2008 the Forum of Responsible Enterprising carried out a study on responsible enterprising among the lodging establishments of Estonia. A total of 46 companies participated in the study (Siller, 2008).

\section{Auditing Model for Estonian Companies}

Most important keyword for the next 10 years is the value of immaterial capital, especially the value of human capital. That depends on how quickly and optimistically we can adapt to changes, how capable are our employees to use high tech technology or create new solutions. The beneficiary depends on how committed and loyal are our employees. Employees are committed to their work, when work conditions and attitudes meet the needs of workers or they are even higher and when they are treated equitably. As in Global Report Initiative (GRI) significant market value derives from intangible assets such as reputation, capacity to innovate, and commitment to social well-being. It will help to identify various components of a company's value that are not always apparent when simply assessing its financial performance. According to Mackenzie (1998), Domingo (2005), and Kaptein (1998), ethics auditing has very little to do with the traditional auditing of accounts. It aims to reflect the extent to which the company meets the economic, social, and environmental demands on which the trust placed in it depends. Ethical auditing is a process of taking account of financial as well as non-financial utilization of resources, delivery of outputs and outcomes of an activity or programme or organization in a participatory manner by consulting all stakeholders. Auditing is about supervising and advising, therefore the results cannot be released to the public, if owners or top managers do not agree with that. There are several reasons to implement auditing process and possibilities to take advantage of that. This is the first attempt to use the ethical audit (or social audit) in Estonian companies. The focus is on evaluating the previous performance and establishing the structure, procedures, criteria, and objectives for next period. Auditing process is carried out by the external auditing committee. The auditing committee should be composed of at least three independent experts. They might be representatives of a cross section of stakeholders 
but it is not suggested in small country and sometimes corrupts Estonian culture. It is difficult to stay impartial expert in described circumstances.

There are three basic restrictions for committee experts:

- He/she has to be active researcher in business ethics. Publishing one-two scientific article per year in a reviewed journal or presentations in conferences;

- He/she should have practical experience in corporate government;

- He/she should not have any kind of interest towards the organization being audited.

Internal partner to committee is the workgroup inside organization to provide for auditors assistance and operative information. To develop ethics auditing for Estonian big and middle size companies built on Estonian capital, the author created a framework, that took into account the goals and indicators of Kaptein (1998) ethics auditing, GRI model and social auditing models. Creating auditing model principles of EU SCR strategy for 2020 (Communication from the Commission, 2010) and ISO 26000 model are supporting as well.

There are some meaningful aspects that author would like to stress modelling auditing process. Before collecting information, it is necessary to find out companies main strategies, principles of management and operations. After this, the author can continue with identifying the values, aims (mission), and objectives of the organization. Attention must be paid to the fact that all data used in a regulation, is up to date, if there are internal regulations like code of conduct, if the code of conduct is fictive or it has real practical value. If $20 \%$ of Estonian companies have code of ethics or code of conduct, then at least $80 \%$ of them are fictive. It means that they are obligatory to have, but they are never followed. Hereby presented auditing model takes into account following strategies and activity fields:

- General Government;

- Personnel policies;

- Economic effectiveness;

- Law-abiding;

- Environmental performances;

- Sustainability.

An auditing process is divided into parts and it depends on companies needs, which part is receiving more attention during the process. Audit can be tailor-made for each company, but there should be some common principles and parts to compare with other companies. Employees and managers will encounter novel situations in their jobs and will need ethical guidelines to handle them effectively.

\section{Auditing Process}

The auditing process includes several activities, which are described as follows.

\section{Defining Audit Boundaries for an Organization}

- Purpose and expected outcome of the ethical auditing;

- Identifying key stakeholders group;

- Detailed planning of auditing process.

\section{Collecting an Information}

Observation of documents:

- Reviewing the aims and objectives set out in the organization's business plan, operational plan, and 
constitution or funding proposals;

- Previous SWOT analysis ;

- Minutes of board meetings ;

- Annual and management reports;

- Internal regulations etc..

Questioning and interviewing stakeholders:

- Owners and top managers (how are they used? and how they are involved?)

- Employees;

- Customers (products and services, safety);

- Partners;

- Suppliers (honesty, payment rules);

- Society (environment and local habitants);

- Competitors.

In the questionnaire, the ethical aspects will be quantified by requesting each stakeholders representatives ( $n=$ ca 50) to give their opinion on a diversity of propositions on Likert-type scale from 1 to 5 , where 1 is absolutely disagree and 5 is agree completely. For each stakeholders group, a special questionnaire will be worked out. A sample question from survey forms, worked out by the author, for employees is given in Appendix A. Some questions require a simple yes/no answer, some are open type questions and require the respondent to write an answer or an opinion. The questionnaire is divided into three parts-first part gives basic information of organization, second part gives overview of personal, and third part is about employee's common moral attitude and ethical behaviour to understand employee's responsibilities in organizational success and ethics.

Additionally, a multiple choice integrity test can be used. It helps to find out employees thoughts, feelings and expected behaviours in matter of ethical aspects. Usually this paper and pencil honesty test is used as a stage in selection process among job applicants, but it is valuable data source in auditing process as well (Kaptein, 1998). In Estonian model, this part is important because of its historical culture perspective, where stealing behind employer is common and everyone's right. There are some rudimentary from Soviet time that still belong to our employees accepted norm. Indicator requirements:

- Meaningful and significant: An indicator must tell something about what organization is trying to achieve;

- Measurable: An indicator must be able to show change, through numbers or level of satisfaction;

- Simplicity: If an indicator is too complex it may be ignored, or misunderstood;

- Comparability;

- All indicators are indirect measures that tell us whether organization is making progress toward achieving ethical behaviour and expectation of stakeholders.

After questioning a statistical qualitative, analyses will be done. Measures represent the proportion of employees who respond with agree and strongly agree to selected questions. From this analysis could come out contradictions between or in stakeholders group. It means that the difference between what is said and what is done, or what people do and what other people think they do. Results of this analysis will show if there are any contradictions between or in the stakeholders group. If there are any differences between what is said or written and what is the reality. To clarify and determine this contradictions focus group or personal interviews will be held. A concentration is towards ethical aspects and findings from questionnaire analyses. A personal interview 
is more effective because interviewees may not be so open among co-workers or stranger people. This is the most important part of the auditing process since it gives adequate information to the auditors. If needed, SWOT analyses will be done by stakeholders group. Each focus group's participant identifies and writes down on cards, what they think of the organization in terms of its strengths, weaknesses, opportunities and threats. After that, most important areas will be prioritised and secondary areas discarded.

Hereby, some examples of an interview question for employees are given:

- Who helps employees to solve ethical conflicts or misbehaviour?

- Do you have adequate information for doing your job accurately?

- What are your expectations towards the organization within next five years?

- What do you do if the work regulations do not support your interests?

- How you feel that you are treated by your colleges and manager?

- Do you think that the owner/employer is honest with the employees? Give an example.

\section{Auditing Committee Walking Tours in Company (Factory, Office, Storehouse ect.)}

During walking tours real picture of organization will open to the auditors, real work conditions will be photographed.

Table 1 gives a general overview about the data sources, which auditors can use during the auditing process to collect information.

Table 1

Data Sources and Fields of Governance/Strategies

\begin{tabular}{|c|c|c|c|c|c|}
\hline $\begin{array}{l}\text { Stakeholders group } \\
\text { A field }\end{array}$ & $\begin{array}{l}\text { Board of Directors } \\
\text { and owners }\end{array}$ & Employees & Customer & $\begin{array}{l}\text { Society } \\
\text { (environment) }\end{array}$ & $\begin{array}{l}\text { Partner } \\
\text { and supplier }\end{array}$ \\
\hline General govern & $\begin{array}{l}\text { Mission, vision, } \\
\text { strategic goals }\end{array}$ & $\begin{array}{l}\text { Involvement when } \\
\text { working rout } \\
\text { strategies, dialogue } \\
\text { in case of critical } \\
\text { decisions. } \\
\end{array}$ & $\begin{array}{l}\text { Policies } \\
\text { procedures } \\
\text { dealing } \\
\text { customer } \\
\text { complaints. } \\
\end{array}$ & $\begin{array}{l}\text { Compliance with } \\
\text { internet standards, } \\
\text { ability to manage } \\
\text { local environmental } \\
\text { crises }\end{array}$ & $\begin{array}{l}\text { Honesty } \\
\text { credibility, back } \\
\text { taxes, cases of } \\
\text { bribes }\end{array}$ \\
\hline Personal policies & \begin{tabular}{|lr} 
Training & plan, \\
number of & cases in \\
labour & dispute \\
committee & \\
\end{tabular} & $\begin{array}{l}\text { Recruitment } \\
\text { and dismissal, } \\
\text { trainings in last } \\
\text { three years }\end{array}$ & 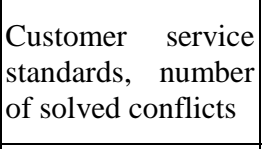 & $\begin{array}{lr}\text { Percentage } & \text { of } \\
\text { indigenous } & \text { among } \\
\text { employees } & \end{array}$ & $\begin{array}{l}\text { Mobility, } \\
\text { capacity }\end{array}$ \\
\hline Economic effectiveness & $\begin{array}{l}\text { Annual reports, } \\
\text { return of investments }\end{array}$ & $\begin{array}{l}\text { Workforce } \\
\text { productivity }\end{array}$ & Price and quality & Cost of office trash & $\mathrm{x}$ \\
\hline $\begin{array}{l}\text { Compliance with laws } \\
\text { and regulations }\end{array}$ & $\begin{array}{l}\text { Regulation of } \\
\text { accounting, number } \\
\text { of court cases, } \\
\text { cost of jur. } \\
\text { consultation. }\end{array}$ & $\begin{array}{l}\text { Cases of } \\
\text { discrimination, } \\
\text { inequality, } \\
\text { remuneration, } \\
\text { undeclared salary. } \\
\end{array}$ & $\begin{array}{l}\text { The number } \\
\text { cases of bribes }\end{array}$ & $\begin{array}{l}\text { Environment } \\
\text { pollutions }\end{array}$ & $\begin{array}{l}\text { International } \\
\text { standards }\end{array}$ \\
\hline $\begin{array}{l}\text { Relationship } \\
\text { with local community }\end{array}$ & $\begin{array}{l}\text { Involvement in } \\
\text { social activities, } \\
\text { sponsorship. }\end{array}$ & $\begin{array}{lr}\text { Family } & \text { activities, } \\
\text { donations } & \text { (in case of } \\
\text { birth, } & \text { marriage, } \\
\text { death) } & \\
\end{array}$ & $\begin{array}{l}\text { Fair } \\
\text { policies }\end{array}$ & $\mathrm{x}$ & $\mathrm{x}$ \\
\hline
\end{tabular}

\section{Risk Mapping}

Mapping the risks helps to identify, evaluate and prioritize a group of risks, which could significantly influence companies or business unit's ability to accomplish its strategies. Only risks are taken into account, which can occur due to unethical behaviour, illegal action or non-value based management. Hereby, in auditing the author talks about strategic-, transaction-, reputation- and regulatory/compliance risks. 
Using the Arthur Andersen Business Risk Model (Auditnet, 2010), several business risks which could significantly impact a company's ability to accomplish its business strategies have been identified. The risk that changes in regulations and actions by regulators can result in increased competitive pressures and significantly affect the company's ability to efficiently conduct business. The Risk Map prioritizes each risk according to significance and likelihood and maps the risks into four quadrants.

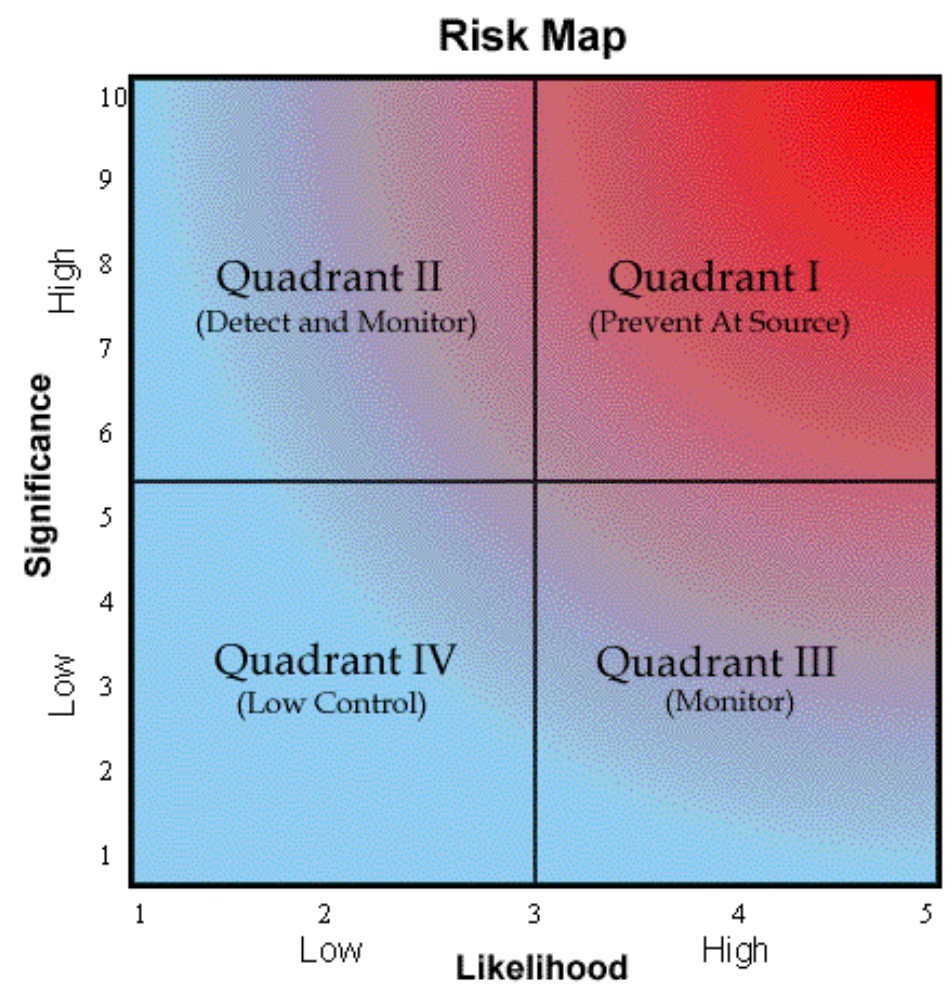

Figure 1. Arthur Andersen Business Risk Model (Auditnet, 2010).

(1) Quadrant "Prevent at Source” risks.

Risks in this quadrant are classified as Primary Risks and are rated "high" priority. They are the critical risks that threaten the achievement of company objectives. These risks are both significant in consequence and likely to occur. They should be reduced or eliminated with preventative controls and should be subject to control evaluation and testing.

(2) Quadrant “Detect and Monitor” risks.

Risks in this quadrant are significant, but they are less likely to occur. To ensure that the risks remain low likelihood and are managed by the company appropriately, they need to monitor on a rotational basis. Detective controls should be put into place to ensure that these high significance risks will be detected before they occur. These risks are second priority after Primary Risks.

(3) Quadrant “Monitor” risks.

Risks in this quadrant are less significant, but have a higher likelihood of occurring. These risks should be monitored to ensure that they are being appropriately managed and that their significance has not changed due to changing business conditions. 
(4) Quadrant “Low Control” risks.

Risks in this quadrant are both unlikely to occur and not significant. They require minimal monitoring and control unless subsequent risk assessments show a substantial change, prompting a move to another risk category.

Risk assessment survey will be presented in Table 2, where significance is rated on scale 1-10 (1-week and 10 strong) and likelihood of occurrence is rated on scale 1-5 (1-likelihood of occurrence is low and 5 is high).

Table 2

Significance and Likelihood of Risks

\begin{tabular}{lll}
\hline Risk & Significance (rate 1-10) & Likelihood of occurrence (1-5) \\
\hline Hard to recruit highly qualified employees & 8 & 5 \\
\hline
\end{tabular}

An example above illustrates the circumstances where risk to recruit new employee is very high and at same time quite significant. It falls into Quadrant I, suggesting that this risk should be Prevented at Source. These are critical risks that threaten the achievement of company objectives. The completed risk map should give a basis for assessing risks and addressing each one in accordance with its potential impact on business strategy.

\section{Writing and Presenting the Final Reports to the Council or Board}

Auditing report provides multifaceted and factual information and describes the performance of the organization, the problems and solutions. Auditing report includes an analysis for all investigated fields according to Table 1. Independent and external auditors verify that the information is accurate and relevant. Report also includes a risk analysis and suggestions on how to eliminate most significant and obviously rising risks.

According to the agreement with CEOs or directors, the results are presented fully or partially to the stakeholders. Each part of the audit could be handled separately.

Report should also include a variance analysis between the year's planned and actual achievements, a general statement about the organization's overall performance in relation to the management statement and trends from one year to the next, if that evidence has been generated. The ethical audit report should have a self evaluation of the auditing team regarding the positive and negative factors involved in the audit.

Auditing committee will gives guidance regarding which stakeholder should be consulted in the next social accounting cycle and appropriate methods of consultation in the future.

After the report is presented, a clear action plan and timetable will be prepared. Planned activities should be measurable in order to guarantee their effectiveness.

\section{Follow up Activities}

Evaluation of the audits effectiveness would be done in cooperation with managers. For that reason organization should compile a work group who guarantees that all suggested activities will be implemented as prescribed. Periodic review of the ethical audit programme should be conducted by a control group, which involves as many stakeholders as possible. Not before than six months after the audit, same focus groups should be interviewed again to ensure, that planned activities were successful. Next audit should take place in two years; in this case auditors have opportunity to gather comparing materials. 


\section{Conclusions}

Ethics auditing gives possibilities for brand and reputation enhancement, differentiation in the marketplace, protection from brand erosion resulting from the actions of suppliers or competitors, networking and communications. Ethic auditing is a valuable tool for managers. It provides possibility for cutting costs, increasing turnover, improving corporate identity and image. This is a great instrument to measure and improve corporate ethics and moral duty. For Estonian credibility and the country's economic growth the following topics, such as the adaption of the euro, the labour market, the balance of the current account or the credibility of the banking sector, cannot be solved or analyzed completely before the economic climate is not trustworthy, transparent and based on same values as in developed old western countries. Then the unanimous dialogue can take place. Model, presented in this article is general, but also significant and unique.

(1) This auditing model follows an advisory approach. No punishments or repressions are carried out. Second auditing could be based on a preventative or even repressive approach. At first, we need to introduce Estonian managers to a new way of thinking, to show, that higher ethical behaviour and ethical management are the ways for survival at global market in long term perspective;

(2) Several problems are caused by dishonesty and cheating, which are the rudiments or heritage from Soviet moral. Estonian society (including economy) has changed rapidly during the last 20 years from socialism towards free market economy. People took over the economic examples from European countries, but did not adapt new manners, relations and principles of the management;

(3) This model covers widely spread misbehaving problems like undeclared salaries, bribes, mental violation at work relations, discrimination, and cheating.

Attention has been paid to question of responsibility of employees. Employer and manager cannot be blamed for unethical behaviour or incidence at workplace. It is question of personal responsibility, about personal role in organizational sustainability and effectiveness. It is a wide, but less talked problem in all over the world and it should get more focus in the future. Through value based management we have to combine employees' interests with value and profit/loss in business (Lin \& Tang, 2009). It is important, that all stakeholder groups follow good common values;

(4) Obstructions may occur in the auditing process due to manager's lack of interest and time to deal with ethics questions. In fact, there is need to change the way of thinking and reorient principles of corporate governance. Unfortunately social responsibility, value based management, and business ethics are not self-evident, but fortunately there are lot of possibilities to show for managers how much benefit and profit could be taken from the value based on management in long term perspective. One already discussed possibility is to implement trade mark like Ethical Corporation which can be used as PR instrument in local and an international market.

\section{References}

Auditnet, The Global Resource for Auditors. (2010). Risk assessment survey and risk mapping tool. Retrieved from http://www.auditnet.org/docs/risk1.doc

Boyd, G., \& Albee, A. (1998). Social auditing-A method of determining impact, the Caledonia centre for social development. Retrieved 5 July, 2012, from http://www.caledonia.org.uk/socialland/social.htm

Büscher, M., Domingo, G. M., \& De Geer, H. (2005). Integrating the ethical perspective (pp. 303-342). München and Mering: Rainer Hampp Verlag. 
Centre for good governance. (2005). Social Audit: A toolkit-A guide for performance improvement and outcome measurement. Retrieved from http://www.unpan1.un.org/intradoc/groups/public/documents/cgg/unpan023752.pdf

Clark, S. (2004). Ethics audit essential for every business. The Business Journal of Milwaukee. Retrieved 12 March, 2004 , from http://www.bizjournals.com/milwaukee/stories/2004/03/15/smallb2.html\#ixzz0ucK84IYJ

Communication from the Commission Europe 2020. (2010). A strategy for smart, sustainable and inclusive growth. Retrieved from

http://www.ec.europa.eu/eu2020/pdf/COMPLET\%20EN\%20BARROSO\%20\%20\%20007\%20-\%20Europe\%202020\%20-\% 20EN\%20version.pdf

Covey, S. (2004). Printsiipidekeskne juhtimine (pp. 19-27). Tallinn: Ilo.

Domingo, G. M. (2005). Trust and dialogue: Theoretical approaches to ethics auditing. Journal of Business Ethics, 57, $209-219$.

Duska, R. F. (2007). Contemporary reflections on business ethics. Issues in Business Ethics, 23, 239-240. Dortrecht: Springer.

Finegold, D., Bensimon, C. M., Daar, A. S., Eaton, M., Godard, B., Knoppers, B. M., ... Singer, P. A. (2005). Bioindustry ethics (pp. 35-37). Boston. M.A.: Elsevier Academic Press.

Johnston, D. J. (2004). OECD principles of corporate governance. Retrieved from http://www.oecd.org/dataoecd/32/18/31557724.pdf

Kaptein, M. (1998). Ethics Management: Auditing and Developing the Ethical Content of Organization. Kluwer Academic.

Kaptein, M. (2004). Business Codes of Multinational Firms: What do they say? Journal of Business Ethics, 50, $13-31$. doi10.1023/B:BUSI.0000021051.53460.da

Lehtsaar, H. (2010). Ettevõtte väärtused mõjutavad eesmärkide saavutamist. Retrieved from http://www.juhtimine.ee/763108/ettevotte-vaartused-mojutavad-eesmarkide-saavutamist/

Lin, G. T. R., \& Tang, J. Y. H. (2009). Appraising intangible assets from the viewpoint of value drivers. Journal of Business Ethics, 88, 679-689. doi 10.1007/s10551-008-9974-y

Mackenzie, C. (1998). Ethical auditing and ethical knowledge, Journal of Business Ethics, 17(13), 1395-1402.

Murphy, J. G. (2008). People in Business: Context and character leadership and business ethics, Business Ethics, 25. Springer Netherlands. doi 117-12910.1007/978-1-4020-8429-4_8

Parthasarathy, M. (1988). Social Audit and its relevance to audit of public utilities, Asian Journal of Government Audit. Retrieved from http://www.asosai.org/asosai_old/journal1988/social_audit_and_its_relevance.htm

Principles of Corporate Governance. Retrieved from http://www.oecd.org/dataoecd/32/18/31557724.pdf

Rosthorn, J. (2000). Business ethics auditing-More than a stakeholder's toy. Journal of Business Ethics, 27, 9-19.

Siller, M. (2008). Vastutustundliku ettevõtluse uuring. Retrieved from

http://www.csr.ee/orb.aw/class=file/action=preview/id=6255/Vastutustundliku+ettev\%F5tluse+uuring+Eesti+majutusettev\% F5tetes.pdf

Spreckley, F. (2008). Social audit toolkit (4th ed.). Local Livelihoods Ltd..

Wheatley, M. J. (2002). Juhtimine ja loodusteadus. Tartu: OÜ Fontes.

\section{Appendix A}

In following section please mark $\mathrm{X}$ if you are agree and add a comments.

Table A1.

An Ethics Auditing Questionnaire for Employees (an Example).

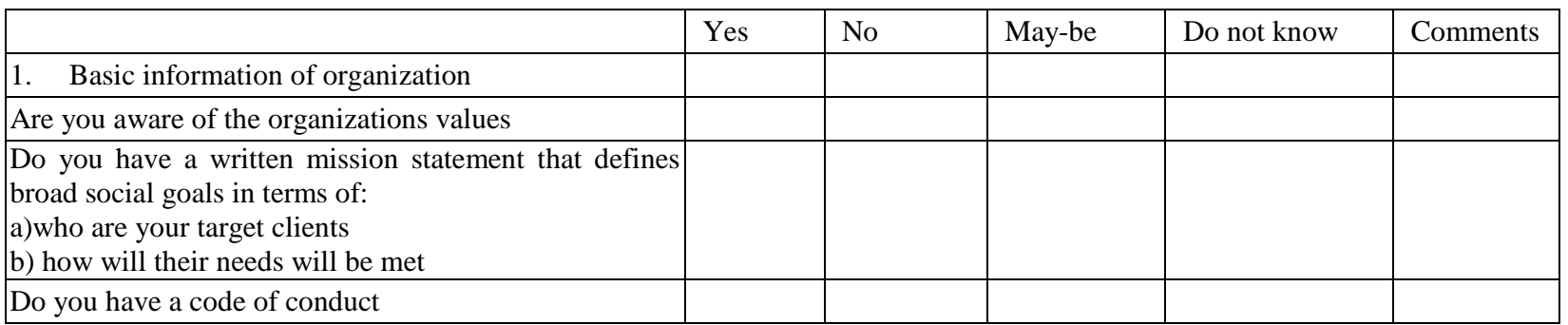

In following part 1 means absolutely disagree and 5 is agree completely 
(Table A1 continued)

\begin{tabular}{|c|c|c|c|c|c|}
\hline & Yes & No & May-be & $\begin{array}{ll}\text { Do not } \\
\text { know }\end{array}$ & Comments \\
\hline 2. Personnel policies & 1 & 2 & 3 & 4 & \\
\hline $\begin{array}{l}\text { The personnel policies are interpreted and used fairly by } \\
\text { managers. }\end{array}$ & & & & & \\
\hline The payment system is fair. & & & & & \\
\hline The incentive wage system in our organization is fair. & & & & & \\
\hline $\begin{array}{l}\text { Managers set a good example by following the } \\
\text { laws and policies that apply to their jobs. }\end{array}$ & & & & & \\
\hline $\begin{array}{l}\text { Managers insist that employees follow the laws and } \\
\text { policies. }\end{array}$ & & & & & \\
\hline $\begin{array}{l}\text { If I have a complaint in my department, it will be handled } \\
\text { fairly. }\end{array}$ & & & & & \\
\hline Recruitment process is transparent. & & & & & \\
\hline Misusing work time is common. & & & & & \\
\hline Personal moral & & & & & \\
\hline $\begin{array}{l}\text { Employees in my work group behave ethically in the } \\
\text { workplace. }\end{array}$ & & & & & \\
\hline Employees in my workgroup take part in decision-making. & & & & & \\
\hline I can report any unethical behaviour. & & & & & \\
\hline $\begin{array}{l}\text { I am confident that quick and decisive action will be taken } \\
\text { if wrongdoing is discovered in my work group. }\end{array}$ & & & & & \\
\hline I am a loyal to the employer. & & & & & \\
\hline I feel valued in my company. & & & & & \\
\hline I feel responsible for the success of organization. & & & & & \\
\hline I feel responsible to satisfy the needs of the customer. & & & & & \\
\hline I work as much as minimally required. & & & & & \\
\hline I would like to participate in decision-making. & & & & & \\
\hline If possible, I cheat my employer. & & & & & \\
\hline $\begin{array}{l}\text { I believe that there is no need to be at workplace to fill the } \\
\text { working hours, if the work is done. }\end{array}$ & & & & & \\
\hline $\begin{array}{l}\text { In case of misbehaviour I am able to admit the committed } \\
\text { mistakes. }\end{array}$ & & & & & \\
\hline I have a strong commitment to my employer. & & & & & \\
\hline My values and the values of my department are similar. & & & & & \\
\hline I rate my personal ethics highly. & & & & & \\
\hline I rate my manager's ethics highly. & & & & & \\
\hline It should be always clear, what is the right thing to do. & & & & & \\
\hline $\begin{array}{l}\text { Ethics depends on the context and the consequences of } \\
\text { actions. }\end{array}$ & & & & & \\
\hline Virtuous person do not need rules of ethics. & & & & & \\
\hline I replied to the questions honestly. & & & & & \\
\hline
\end{tabular}

